\title{
Mutations in the phosphatidylinositol 3-kinase pathway: role in tumor progression and therapeutic implications in breast cancer
}

\author{
Todd W Miller, ${ }^{1,2}$, Brent N Rexer ${ }^{2,3}$, Joan T Garrett ${ }^{3}$ and Carlos L Arteaga ${ }^{1,2,3,4 *}$
}

\begin{abstract}
Mutations in genes that constitute the phosphatidylinositol 3-kinase (PI3K) pathway occur in $>70 \%$ of breast cancers. Clinical and experimental evidence suggest that PI3K pathway activation promotes resistance to some of the current breast cancer therapies. PI3K is a major signaling hub downstream of human epidermal growth factor receptor (HER)2 and other receptor tyrosine kinases. PI3K activates AKT, serum/glucocorticoid regulated kinase (SGK), phosphoinositide-dependent kinase 1 (PDK1), mammalian target of rapamycin (mTOR), and several other molecules involved in cell cycle progression and survival. In estrogen receptor (ER)+ breast cancer cells, PI3K activation promotes estrogendependent and -independent ER transcriptional activity, which, in turn, may contribute to anti-estrogen resistance. Activation of this pathway also confers resistance to HER2-targeted therapies. In experimental models of resistance to anti-estrogens and HER2 inhibitors, pharmacological inhibition of PI3K/AKT/ mTOR has been shown to overcome drug resistance. Early clinical data suggest that combined inhibition of either HER2 or ER plus inhibition of the PI3K pathway might be an effective strategy for treatment of respective HER2+ and ER+ breast cancers resistant to standard therapies. Here, we review alterations in the PI3K pathway in breast cancer, their association with therapeutic resistance, and the state of clinical development of PI3K pathway inhibitors.
\end{abstract}

*Correspondence: carlos.arteaga@vanderbilt.edu ${ }^{4}$ Division of Hematology-Oncology, VUMC, 2220 Pierce Avenue, 777 PRB, Nashville, TN 37232-6307, USA

Full list of author information is available at the end of the article

\section{Introduction}

The phosphatidylinositol 3-kinase (PI3K) pathway is the most frequently mutated pathway in breast cancer, with mutation and/or amplification of the genes encoding the PI3K catalytic subunits $\mathrm{p} 110 \alpha$ (PIK3CA) and $\mathrm{p} 110 \beta$ $(P I K 3 C B)$, the PI3K regulatory subunit $\mathrm{p} 85 \alpha$ (PIK3R1), receptor tyrosine kinases (RTKs) such as human epidermal growth factor receptor (HER)2 (ERBB2) and fibroblast growth factor receptor (FGFR)1, the PI3K activator $\mathrm{K}$-Ras, the PI3K effectors AKT1, AKT2, and phosphoinositide-dependent kinase 1 (PDK1), and loss of the lipid phosphatases PTEN (phosphatase and tensin homolog) and INPP4B (inositol polyphosphate-4-phosphatase, type II) (Table 1). PI3K is activated by growth factor RTKs and G-protein-coupled receptors (Figure 1). PI3K phosphorylates phosphatidylinositol 4,5-bisphosphate (PIP ${ }_{2}$ to produce phosphatidylinositol 3,4,5-trisphosphate $\left(\mathrm{PIP}_{3}\right)$. In turn, PIP $_{3}$ recruits to the plasma membrane several pleckstrin homology $(\mathrm{PH})$ domain-containing proteins, such as PDK1 and AKT, which, upon activation, drive cell cycle progression and survival. Negative regulation of this pathway is conferred by PTEN and INPP4B, which dephosphorylate $\mathrm{PIP}_{3}$ and $\mathrm{PIP}_{2}$, respectively. Akt phosphorylates and inactivates Tuberin (TSC2), a GTPaseactivating protein of the Ras homologue Rheb. Inactivation of Tuberin allows GTP bound-Rheb to accumulate and activate the mammalian target of rapamycin (mTOR)/Raptor (TORC1) complex, which ultimately regulates protein synthesis and cell growth [1]. mTOR also couples with Rictor to form the TORC2 complex, which phosphorylates and activates AKT at Ser473.

Class IA PI3K isoforms are heterodimeric lipid kinases that contain a p 110 catalytic subunit and a p 85 regulatory subunit. The three genes PIK3CA, PIK3CB, and PIK3CD encode the homologous $\mathrm{p} 110 \alpha, \mathrm{p} 110 \beta$, and $\mathrm{p} 110 \delta$ isozymes, respectively. Expression of p110 $\delta$ is largely restricted to immune and hematopoietic cells, whereas $\mathrm{p} 110 \alpha$ and $\mathrm{p} 110 \beta$ are ubiquitously expressed. PIK3CA mutations are the most common genetic alterations of this pathway in breast cancer, where $\geq 80 \%$ occur within the helical (E542K and E545K) and kinase (H1047R) 
Table 1. Phosphatidylinositol 3-kinase pathway alterations in human breast cancers by molecular subtype

\begin{tabular}{|c|c|c|c|c|c|c|}
\hline \multirow[b]{2}{*}{ Gene (protein) } & \multirow[b]{2}{*}{ Alteration } & \multirow[b]{2}{*}{ Effect on signaling } & \multicolumn{3}{|c|}{ Frequency } & \multirow[b]{2}{*}{ Reference } \\
\hline & & & Luminal (ER+) & HER2+ & Basal (TN) & \\
\hline ErbB2 (HER2) & $\begin{array}{l}\text { Gene amplification or } \\
\text { overexpression }\end{array}$ & $\begin{array}{l}\text { Hyperactivation of ErbB2 } \\
\text { signaling (PI3K, MEK) }\end{array}$ & $10 \%$ & $\sim 100 \%$ & $0 \%$ & [30-32] \\
\hline PTEN & $\begin{array}{l}\text { Loss-of-function } \\
\text { mutation or reduced } \\
\text { expression }\end{array}$ & $\begin{array}{l}\text { Hyperactivation of PI3K } \\
\text { signaling }\end{array}$ & $29-44 \%$ & $22 \%$ & $67 \%$ & {$[6,8,104,105]$} \\
\hline PIK3CA (p110a/PI3K) & Activating mutation & $\begin{array}{l}\text { Hyperactivation of PI3K } \\
\text { signaling }\end{array}$ & $28-47 \%$ & $23-33 \%$ & $8-25 \%$ & $\begin{array}{c}{[6,52,66-68,} \\
105-107]\end{array}$ \\
\hline PIK3CB (p110ß/PI3K) & Amplification & Unknown & \multicolumn{3}{|c|}{$5 \%$ of all cases } & {$[62]$} \\
\hline $\begin{array}{l}\text { IGFIR and INSR (IGF-1R, } \\
\text { InsR) }\end{array}$ & $\begin{array}{l}\text { Receptor activation, } \\
\text { IGFIR amplification }\end{array}$ & $\begin{array}{l}\text { Activates IGF-IR/InsR signaling } \\
\text { (PI3K, MEK) }\end{array}$ & $41-48 \%$ & $18-64 \%$ & $42 \%$ & {$[108,109]$} \\
\hline FGFR1 & $\begin{array}{l}\text { Amplification, activating } \\
\text { mutation }\end{array}$ & $\begin{array}{l}\text { Hyperactivation of FGFR } \\
\text { signaling (PI3K, MEK) }\end{array}$ & $8.6-11.6 \%$ & $5.4 \%$ & $5.6 \%$ & {$[63,110]$} \\
\hline RPS6K1 (p70S6K) & Amplification & Unknown & \multicolumn{3}{|c|}{$3.8-12.5 \%$ of all cases } & [111] \\
\hline INPP4B & $\begin{array}{l}\text { Reduced expression or } \\
\text { genomic loss }\end{array}$ & $\begin{array}{l}\text { Hyperactivation of PI3K } \\
\text { signaling }\end{array}$ & $10-33 \%$ & $54 \%$ & $53 \%$ & {$[64,112]$} \\
\hline PIK3RI (p85a/PI3K) & Inactivating mutation & $\begin{array}{l}\text { Derepression of catalytic activity } \\
\text { of p } 110 a\end{array}$ & \multicolumn{3}{|c|}{$2 \%$ of all cases } & [113] \\
\hline AKT1 & Activating mutation & Hyperactivation of AKT & $2.6-3.8 \%$ & $0 \%$ & $0 \%$ & $\begin{array}{c}{[65,66} \\
106,114]\end{array}$ \\
\hline AKT2 & Amplification & Hyperactivation of AKT & \multicolumn{3}{|c|}{$2.8 \%$ of all cases } & {$[115]$} \\
\hline EGFR & Amplification & $\begin{array}{l}\text { Hyperactivation of EGFR } \\
\text { signaling (PI3K, MEK) }\end{array}$ & \multicolumn{3}{|c|}{$0.8 \%$ of all cases } & {$[116]$} \\
\hline PDK1 & $\begin{array}{l}\text { Amplification or } \\
\text { overexpression }\end{array}$ & $\begin{array}{l}\text { Hyperactivation of PDK1 (AKT, } \\
\text { TORC1) }\end{array}$ & $22 \%$ & $22 \%$ & $38 \%$ & {$[117]$} \\
\hline KRAS & Activating mutation & Hyperactivation of PI3K and MEK & \multicolumn{3}{|c|}{$4-6 \%$ of all cases } & {$[118,119]$} \\
\hline
\end{tabular}

EGFR, epidermal growth factor receptor; ER, estrogen receptor; FGFR, fibroblast growth factor receptor; HER, human epidermal growth factor receptor; IGF-1R, insulinlike growth factor-1 receptor; INPP4B, inositol polyphosphate-4-phosphatase, type II; InsR, insulin receptor; MEK, mitogen-activated protein kinase kinase; PDK1, phosphoinositide-dependent kinase 1; PI3K, phosphatidylinositol 3-kinase; TN, triple negative.

domains of p110 $\alpha$. Such mutations confer increased catalytic activity through different mechanisms [2], but both induce characteristics of cellular transformation, including growth factor- and anchorage-independent growth, and resistance to anoikis [3]. Temporally regulated expression of the H1047R mutant in the mammary gland of transgenic mice induces mammary tumor formation [4]. Genetic or pharmacological inactivation of PIK3CA $A^{\text {H1047R }}$ expression results in disappearance of mammary tumors. However, some of these recur and become insensitive to PI3K inhibition via c-myc overexpression [5].

PI3K pathway alterations frequently co-occur in breast cancer, suggesting that they confer advantages to cancer cells by different mechanisms. For example, PIK3CA mutations sometimes occur in breast tumors harboring PTEN loss or HER2 overexpression [6-8]. p110 $\alpha$ is essential for signaling and growth of tumors driven by PIK3CA mutations, RTKs, and/or mutant Ras, whereas $p 110 \beta$ lies downstream of G-protein-coupled receptors and has been shown to mediate tumorigenesis in PTEN-deficient cells [9]. HER2 overexpression and PIK3CA mutations are commonly found in both ductal carcinoma in situ and invasive breast cancers. However, PIK3CA mutations are found at a lower frequency in intraepithelial neoplastic lesions. This suggests that PIK3CA mutations can further augment PI3K pathway activation mediated by other oncogenes such as ERBB2 (HER2) [10-14].

Molecular analyses have shown that breast cancer is a collection of diseases that generally fit into three subtypes that respond to different therapeutics and exhibit a different natural history. Breast cancers that express estrogen receptor $\alpha(E R)$ and/or progesterone receptor (PR) are hormone-dependent and, as such, respond to therapies that inhibit ER signaling by multiple mechanisms. HER2-positive cancers exhibit amplification or overexpression of the ERBB2 (HER2) proto-oncogene and respond clinically when treated with HER2-directed therapies. Triple-negative breast cancers (TNBCs), which lack detectable expression of ER, PR, and HER2, have no approved targeted therapy and are treated with traditional chemotherapy. Therefore, we will separately 


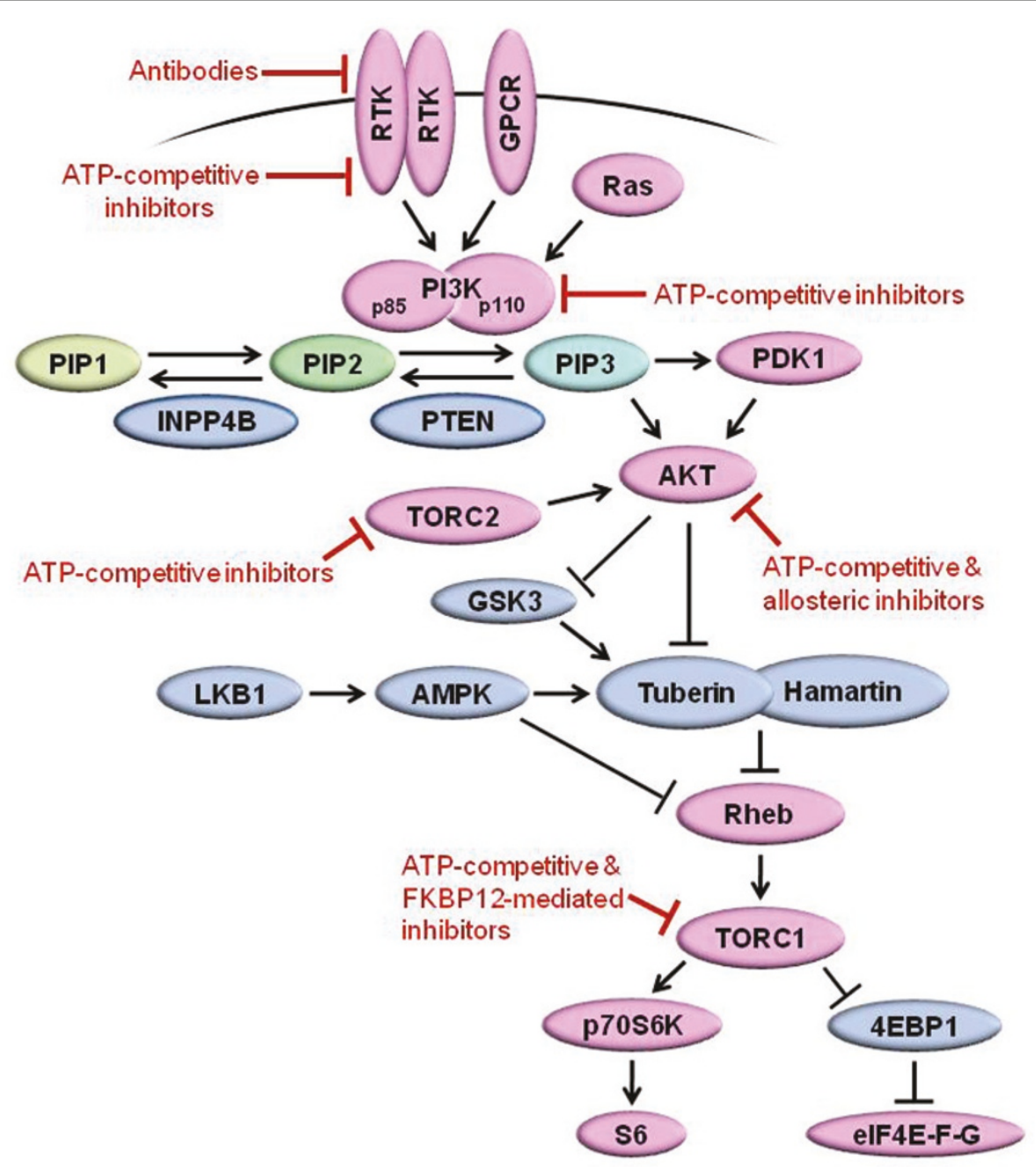

Figure 1. Diagram of the phosphatidylinositol 3-kinase signaling pathway. Tumor promoters and suppressors are labeled in pink and blue, respectively. Nodes targeted by drugs in clinical development are shown in red. AMPK, AMP-activated protein kinase; GPCR, G-protein-coupled receptor; GSK3, glycogen synthase kinase 3; INPP4B, inositol polyphosphate-4-phosphatase, type II; LKB1, liver kinase B1; PDK1, phosphoinositidedependent kinase 1; PI3K, phosphatidylinositol 3-kinase; PIP1, phosphatidylinositol monophosphate; PIP2, phosphatidylinositol 4,5-bisphosphate; PIP3, phosphatidylinositol 3,4,5-trisphosphate; PTEN, phosphatase and tensin homolog; RTK, receptor tyrosine kinase.

review the roles of molecular alterations in the PI3K pathway in each breast cancer subtype and their clinical implications.

\section{PI3K pathway inhibitors in clinical development}

Several drugs targeting multiple levels of the PI3K network (that is, PI3K, AKT, mTOR) are in clinical development in breast cancer. The first group encompasses ATP mimetics that bind competitively and reversibly to the ATP-binding pocket of p110; some of these compounds also bind and inhibit mTOR (Table 2). Notably, the pan-PI3K and $\mathrm{p} 110 \alpha$-specific inhibitors are equally potent against oncogenic mutants of p110 $\alpha$ $[15,16]$. A second group includes allosteric and ATPcompetitive inhibitors of the three isoforms of AKT; these have also shown antitumor activity in preclinical models [17-19] and recently entered human trials. Allosteric inhibitors such as MK-2206 bind to the PH domain and/or hinge region in AKT to promote an inactive conformation and thus prevent localization (and activation) of AKT to the plasma membrane [19]. The macrolide rapamycin and its analogs (rapalogs) complex with FK506-binding protein (FKBP12), which then binds to mTOR and inhibits the kinase activity of TORC1 but not TORC2 [20]. Formulation problems with rapamycin and its inability to effectively inhibit phosphorylation of 4E-BP proteins (which are TORC1 substrates that promote translation) prompted the development of analogs that have shown cytostatic activity in preclinical models and clinical trials [20]. Compounds that target 
Table 2. Phosphatidylinositol 3-kinase pathway inhibitors in clinical development

\begin{tabular}{|c|c|c|c|}
\hline Kinase target & Drug & Manufacturer & Mechanism of action \\
\hline \multirow[t]{5}{*}{ Pan-PI3K } & BKM120 & Novartis & ATP-competitive \\
\hline & $X L-147$ & Exelixis & ATP-competitive \\
\hline & PX-866 & Oncothyreon & ATP-competitive \\
\hline & GDC-0941 & Genentech/Roche & ATP-competitive \\
\hline & CH5132799 & Chugai Pharma & ATP-competitive \\
\hline p1108-specific & CAL-101 & Calistoga & ATP-competitive \\
\hline \multirow[t]{3}{*}{ p110a-specific } & BYL719 & Novartis & ATP-competitive \\
\hline & GDC-0032 & Genentech/Roche & ATP-competitive \\
\hline & INK-1117 & Intellikine & ATP-competitive \\
\hline \multirow[t]{8}{*}{$\mathrm{PI} 3 \mathrm{~K} / \mathrm{mTOR}$} & PKI-587 & Pfizer & ATP-competitive \\
\hline & BEZ235 & Novartis & ATP-competitive \\
\hline & BGT226 & Novartis & ATP-competitive \\
\hline & PF-4691502 & Pfizer & ATP-competitive \\
\hline & GDC-0980 & Genentech/Roche & ATP-competitive \\
\hline & $X L-765$ & Exelixis & ATP-competitive \\
\hline & SF1126 & Semafor & ATP-competitive/peptide-conjugate \\
\hline & GSK1059615 & GSK & ATP-competitive \\
\hline \multirow[t]{3}{*}{ TORC1 } & Everolimus (RAD001) & Novartis & Indirect, FKBP12-mediated \\
\hline & Temsirolimus (CCI-779) & Wyeth/Pfizer & Indirect, FKBP12-mediated \\
\hline & Ridaferolimus (AP-23573) & Merck/Ariad & Indirect, FKBP12-mediated \\
\hline \multirow[t]{3}{*}{ TORC1/TORC2 } & INK-128 & Intellikine & ATP-competitive \\
\hline & OSI-027 & OSI Pharm. & ATP-competitive \\
\hline & AZD-8055 & Astrazeneca & ATP-competitive \\
\hline \multirow[t]{5}{*}{ AKT } & AZD5363 & Astrazeneca & ATP-competitive \\
\hline & GDC-0068 & Genentech/Roche & ATP-competitive \\
\hline & GSK690693 & GSK & ATP-competitive \\
\hline & MK-2206 & Merck & Allosteric \\
\hline & VQD002 & Vioquest & ATP-competitive \\
\hline
\end{tabular}

mTOR, mammalian target of rapamycin; PI3K, phosphatidylinositol 3-kinase.

the ATP-binding cleft of mTOR, and are thus active against both TORC1 and TORC2 [21], are also in phase I trials.

Inhibition of TORC1 relieves negative feedback on activators of PI3K (for example, insulin-like growth factor-1 receptor (IGF-1R), insulin receptor substrate 1 (IRS-1), HER3) [22-24], suggesting that direct inhibitors of PI3K may be more effective. However, inhibition of PI3K or AKT also results in feedback upregulation/ activation of several RTKs, which, by providing an input to PI3K, may counteract drug action and/or activate other oncogenic pathways such as the mitogen-activated protein kinase kinase (MEK) pathway [17,25-27]. These data suggest that PI3K/AKT/TORC1 inhibitors could be combined with RTK inhibitors to induce an optimal antitumor effect. Consistent with this notion, studies in human cancer xenografts have shown that combinations of inhibitors targeting HER2 and PI3K, HER2 and AKT, HER2 and TORC1, or epidermal growth factor receptor (EGFR) and AKT are superior to single-agent treatments $[17,22,25,26]$.

\section{PI3K pathway alterations in ER+ breast cancer}

Approximately $75 \%$ of primary breast cancers express ER and/or PR. Such hormone receptor expression typically indicates a degree of estrogen dependence for cancer cell growth. Treatments for these patients inhibit ER function either by antagonizing ligand binding to ER (tamoxifen and other selective estrogen receptor modulators (SERMs)), downregulating ER (fulvestrant), or blocking estrogen biosynthesis (aromatase inhibitors (AIs)). Although endocrine therapies have changed the natural 
history of hormone-dependent breast cancer, $>30 \%$ of patients with early ER+ breast cancer relapse within 15 years following adjuvant therapy with tamoxifen, and approximately $20 \%$ of patients treated with an AI relapse within 9 years $[28,29]$. A mechanism of resistance to endocrine therapy involves overexpression of HER2 [30-32]. However, $<10 \%$ of ER+ breast cancers express high HER2 levels, suggesting that for the majority of ER+ breast cancers, mechanisms of escape from endocrine therapy remain to be elucidated.

In addition to its pro-survival and growth-promoting roles, the PI3K pathway interacts with ER directly [33] and indirectly. ER phosphorylation at Ser167 by AKT or p70S6K increases estrogen-induced, tamoxifen-induced, and ligand-independent ER transcriptional activity [33,34]. Additionally, PI3K and Ras contribute to the modulation of ER and transcription cofactors [35-45]. The activation of ER by growth factor RTK signaling is reciprocated in a feed-forward fashion, whereby ER promotes the transcription of genes encoding receptor ligands, RTKs, and signaling adaptors [45-50]. Clinical evidence further suggests that ER may activate the PI3K pathway. For example, neoadjuvant treatment of patients bearing ER+ breast cancer with the AI letrozole reduces $\mathrm{P}-\mathrm{AKT}_{\mathrm{S473}}, \mathrm{P}-\mathrm{mTOR}_{\mathrm{S} 2448}$, and P-S6 tumor levels; these reductions have been shown to correlate with clinical response [51,52]. Emerging evidence also implicates estrogens in the rapid, non-genomic activation of PI3K via IGF-1R/insulin receptor (InsR), EGFR, Src, PI3K, and MEK [53-56].

PI3K pathway activation has been shown to confer anti-estrogen resistance in various experimental models, including in PTEN-deficient cells, and in cells overexpressing HER2, IGF-1R, or an activated mutant of AKT1 $[33,44,54]$. Tumor cells with acquired endocrine resistance have shown upregulation of IGF-1R, InsR, HER2, and EGFR levels as well as PI3K/AKT/mTOR activation [57-61]. Inhibition of the PI3K pathway reverses such anti-estrogen resistance. However, PI3K or AKT inhibition relieves feedback inhibition of the expression and activation of RTKs, which can contribute to drug resistance $[17,25,26]$. Interestingly, a recent study showed that in ER+ breast cancer cells treated with the PI3K/mTOR inhibitor BEZ235 or with PI3K siRNA, exogenous estradiol prevented drug- and siRNA-induced apoptosis [62]. Since most breast cancers that adapt to anti-estrogen therapy retain ER, these data imply that unopposed estrogen ligands may protect ER+ tumors from the therapeutic effects of PI3K inhibitors used as single agents.

Clinical evidence suggests that activation of PI3K via overexpression of HER2 or FGFR1, or loss of INPP4B also confers anti-estrogen resistance to patients with ER+ breast cancer $[30-32,63,64]$. Whether other mutations in the PI3K pathway correlate with anti-estrogen resistance remains to be determined. PIK3CA mutations occur in 28 to $47 \%$ of ER+ breast cancers. Interestingly, such mutations correlate with good long-term outcome and lower PI3K and TORC1 activation as assessed by gene expression profiling and immunohistochemistry (IHC) in patients bearing ER+ tumors [6,52,65-68]. Despite these findings, preclinical evidence indicates that combined targeting of PI3K and ER is synergistic [69], suggesting that combinations of anti-estrogens and PI3K pathway inhibitors will be clinically more effective than antiestrogens alone.

The correlations between PIK3CA mutations, good patient outcome, and low PI3K pathway activation (measured by gene expression profiling and IHC) beg the need for alternative methods indicative of PI3K pathway activation to identify ER+ tumors at risk of recurrence. For example, a primary breast tumor gene expression signature of PTEN loss, derived from a comparison of PTEN-expressing versus PTEN-negative tumors by IHC, was predictive of poor relapse-free survival following tamoxifen, while PTEN status by IHC was not [8]. Breast cancers of the luminal A and luminal B molecular subtypes (based on gene expression profiling) are typically ER+. However, luminal B tumors benefit less from adjuvant anti-estrogen therapy [70]. Of note, a gene expression signature of PI3K activation, based on tumor levels of a panel of phosphoproteins (for example, P-AKT, P-p70S6K) in ER+ tumors, was enriched in luminal B breast cancers [71]. This suggests that luminal B tumors have higher PI3K activity, which may contribute to their lower response to anti-estrogens compared to luminal A tumors [72]. Similarly, we identified a tumor protein signature of PI3K pathway activation that predicts poor outcome following adjuvant endocrine therapy [58]. Therefore, signatures of PI3K activation may complement mutational analyses for the identification of high-risk, PI3K-driven, ER+ tumors.

Further rationale for combined inhibition of PI3K and ER comes from studies using inhibitors of TORC1 or HER2. In patients with ER+ tumors randomized to neoadjuvant letrozole with or without the TORC1 inhibitor everolimus for 4 months before surgery, the addition of everolimus increased clinical response and suppression of tumor cell proliferation [52]. In the TAMRAD study in patients with metastatic ER+ breast cancer who had progressed on an $\mathrm{AI}$, the addition of everolimus to tamoxifen improved the rate of clinical benefit, time-toprogression, and disease-free survival compared to women receiving tamoxifen alone [73]. Most recently, results from the phase III trial BOLERO-2 showed that treatment with everolimus plus the AI exemestane provided a time-to-progression of 10.6 months compared to 4.1 months with the AI alone in post-menopausal 

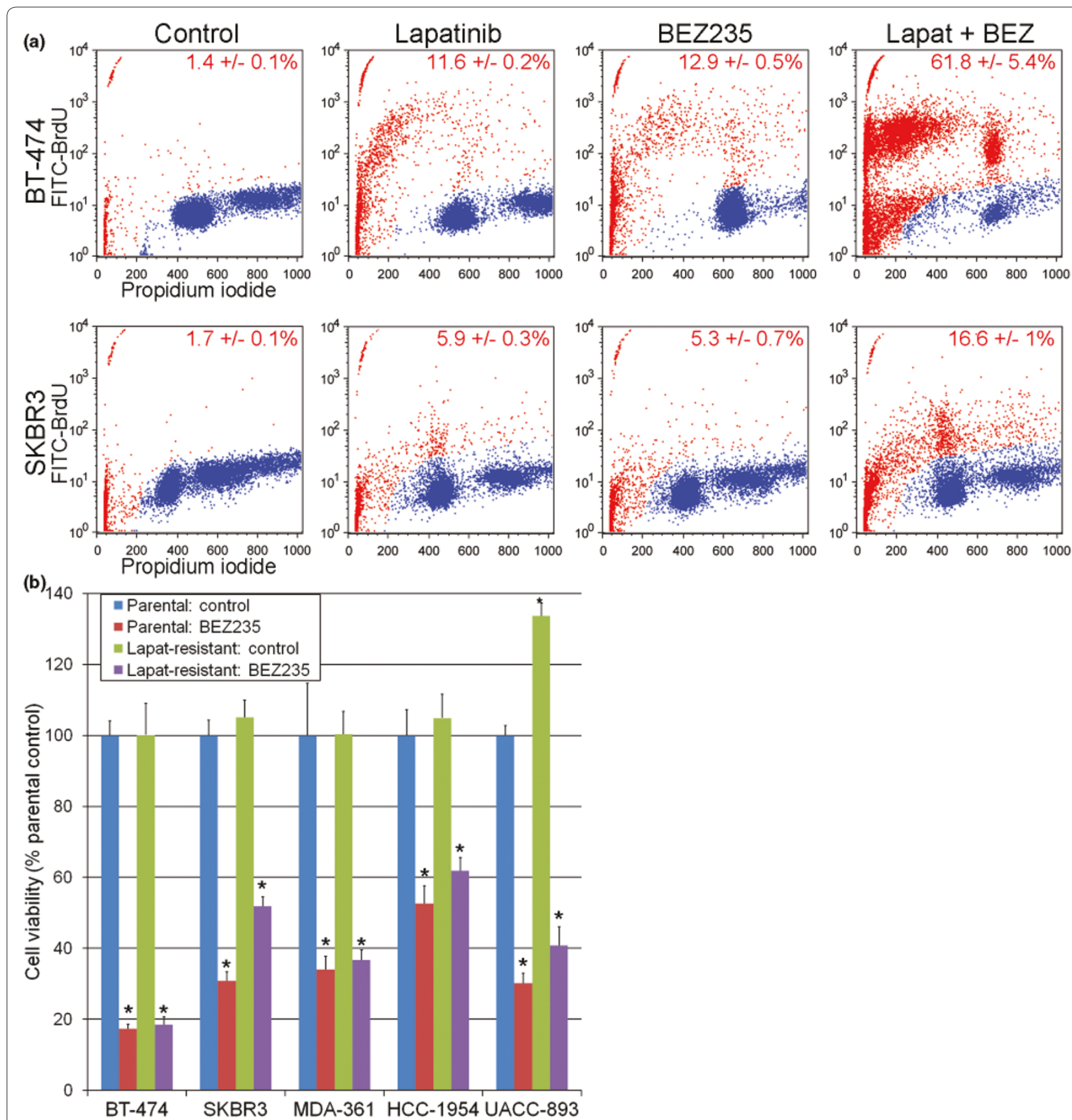

Figure 2. Inhibition of phosphatidylinositol 3-kinase/mammalian target of rapamycin abrogates lapatinib resistance in HER2+ breast cancer cells. (a) BT-474 and SKBR3 cells were serum-starved for 3 days, then treated with or without $1 \mu$ M lapatinib or 250 nM BEZ235 for 2 days. Cells were fixed, stained using the ApoBrdU kit (Phoenix Flow Systems), and analyzed by flow cytometry. Cells were considered apoptotic if they exhibited sub-G1 levels by propidium iodide staining, and/or high fluorescein isothiocyanate (FITC)-bromodeoxyuridine (BrdU) labeling. Representative plots are shown, and the percentage of apoptotic cells (mean of triplicates \pm standard deviation) is noted in each panel; blue, live; red, dead. (b) BT474 and SKBR3 cells were selected for long-term growth in the presence of $2 \mu \mathrm{M}$ lapatinib to generate resistant cells [83]. Parental and lapatinib-resistant cells were treated with or without $250 \mathrm{nM}$ BEZ235 in growth medium (lapatinib-resistant cells were maintained in 2 MM lapatinib). Media and drugs were replenished every 2 to 3 days. Cell viability was measured after 5 to 6 days by WST1 assay (Roche). Data are presented as percentage parental control for each cell line, mean of triplicates \pm standard deviation. ${ }^{*} P<0.05$ by Bonferroni post-hoc test compared to parental control.

women with advanced breast cancer who had recurred or progressed on prior endocrine therapy [74].
The ER and PI3K pathways appear to exist in an equilibrium, where tumors with low PI3K activation have 
high ER levels, and vice versa [58,71]. The interdependence of these pathways is supported by studies showing that inhibition of HER2 with the antibody trastuzumab or the tyrosine kinase inhibitor lapatinib restores or upregulates ER levels or transcriptional activity in breast cancer cells and patient tumors. Furthermore, treatment with AIs or fulvestrant inhibits the growth of HER2+ tumors that had progressed on trastuzumab or lapatinib [75,76]. These data suggest that combined inhibition of ER and HER2, an RTK that potently activates PI3K, may provide more effective control of ER+/HER2+ tumors. Indeed, two clinical trials showed that the addition of trastuzumab or lapatinib to therapy with an AI increased progression-free survival and clinical benefit compared to the AI alone $[77,78]$.

\section{PI3K alterations in HER2+ breast cancer}

Most patients bearing breast cancers with amplification or overexpression of HER2 benefit from anti-HER2 therapy. However, most patients with HER2+ metastatic disease eventually acquire resistance to trastuzumab, lapatinib, and the combination [79-81]. HER2 potently activates PI3K via heterodimerization with HER3, and other PI3K pathway activating mutations often coexist in HER2+ cancers (Table 1). Experimental and clinical evidence suggest that mutational activation of the PI3K pathway confers resistance to HER2-directed therapies, perhaps by providing an additional input to this pathway independent of HER2/HER3 dimers. HER2+ breast cancer cell lines are highly sensitive to PI3K and mTOR inhibitors before and after acquiring resistance to trastuzumab or lapatinib [22,82,83] (Figure 2). These data suggest that these drug-resistant cells remain PI3Kdependent, and that patients with trastuzumab- and/or lapatinib-resistant disease would benefit from PI3K pathway inhibitors.

Retrospective analyses of cohorts of patients with HER2+ metastatic breast cancer have shown that tumors harboring PIK3CA mutations and/or decreased levels of PTEN have a poor outcome following treatment with trastuzumab compared to HER2+ tumors with a 'wildtype' PI3K pathway [84-87]. In addition, a neoadjuvant study in patients with HER2+ breast cancer showed that both alterations (PIK3CA mutations and PTEN loss) were associated with a statistically lower pathological complete response rate to trastuzumab with chemotherapy. However, tumors with decreased PTEN responded to neoadjuvant therapy with lapatinib followed by trastuzumab and chemotherapy [88]. Pending confirmation of this report, these data suggest that PTEN-deficient HER2+ cancer cells still rely heavily on upstream input from HER2 and, therefore, dual blockade of HER2 with trastuzumab and lapatinib is effective against HER2+/PTEN-deficient breast cancers. A few studies suggest that combined targeting of HER2 and the PI3K pathway is superior to HER2-directed therapy alone. In patients who had progressed on trastuzumab and chemotherapy, the addition of the TORC1 inhibitor everolimus to trastuzumab and chemotherapy conferred a 19 to $44 \%$ objective response rate [89-91]. Preclinical studies also suggest that because of the reactivation of HER3 following inhibition of PI3K/AKT/TORC1 in HER2-overexpressing breast cancer cells, PI3K inhibitors should be given in combination with anti-HER2 therapy in patients with HER2 tumors $[22,25,92]$. At this time, patients with drug-resistant HER2+ breast cancer are a subgroup of intense focus in exploratory trials with PI3K pathway inhibitors.

\section{PI3K pathway mutations in triple-negative breast cancer}

Since ER, PR, and HER2 are established molecular markers associated with response to targeted therapies, ER-/PR-/HER2-negative cancers are loosely grouped as TNBCs. Such cancers occur in 10 to $15 \%$ of patients, are associated with earlier age at diagnosis, poor prognosis, and BRCA1 mutations, and are more prevalent in African-American and Hispanic women [93]. By gene expression profiling, TNBCs cluster separately from ER+ and HER2+ cancers, mainly within the basal-like molecular subtype. A recent analysis revealed that TNBCs can be divided into six subtypes [94]. Interestingly, the 'mesenchymal-like' and 'mesenchymal stemlike' subtypes exhibit enrichment for components of growth factor signaling pathways, including inositol phosphate metabolism. Growth of breast cancer cell lines classified as 'mesenchymal-like,' 'mesenchymal stem-like', or 'luminal androgen receptor subtype' was inhibited by the PI3K/mTOR inhibitor BEZ235. Cell lines of the 'luminal androgen receptor subtype' exhibit a high frequency of PIK3CA mutations. In contrast, PTEN status did not correlate with sensitivity to BEZ235. PTEN has functions outside of the PI3K pathway, including in DNA double-strand break repair. In addition, BRCA1 mutations impair double-strand break repair and correlate with the presence of PTEN mutations [95], and PTEN knock-down has been shown to sensitize BRCA1mutant cancer cells to poly(ADP-ribose) polymerase (PARP) inhibition [96,97]. Thus, it is conceivable that PTEN-deficient cells may respond to combined PI3K/ PARP-directed therapy.

The standard treatment for patients with TNBC includes mainly DNA-damaging chemotherapy. PI3K pathway mutations have been associated with resistance to such agents, likely by promoting cell survival. Also, DNA damage elicits DNA-dependent protein kinasemediated phosphorylation of AKT [98]. Preclinical studies in diverse cancer cell types have shown that PI3K 
inhibitors enhance the apoptotic effects of DNAdamaging agents [99-102]. Clinical trials are ongoing to test such drug combinations in patients with TNBC.

\section{Conclusions}

Somatic mutations in the PI3K pathway identify cancers with aberrant activation of, and potential dependence on, this signaling pathway. These attributes may be useful for the selection of patients for trials with PI3K inhibitors. Indeed, a recent analysis of patients with solid tumors enrolled in phase I trials with PI3K/AKT/mTOR inhibitors showed a higher response rate among patients with PIK3CA-mutant versus wild-type PIK3CA cancers [103]. This suggests that tumors with gain-of-function mutations in the PI3K pathway depend on PI3K signaling, and this dependence can be exploited in patients with such cancers. There is increasing agreement that initial phase II efficacy studies with PI3K inhibitors in patients with advanced disease should be enriched with, if not limited to, patients harboring mutations and/or activation of this pathway. As with other targeted therapies, only a fraction of patients will likely benefit from single-agent PI3Kdirected therapy. PI3K pathway inhibitors are being tested in human trials in combination with inhibitors of HER2, MEK, and ER. Early clinical data suggest that this strategy is feasible and that, as single agents, these drugs are well-tolerated. To determine if inhibition of PI3K confers a benefit compared to standard targeted therapies alone will require randomized clinical trials.

\section{Abbreviations}

$\mathrm{Al}$, aromatase inhibitor; EGFR, epidermal growth factor receptor; ER, estrogen receptor; FGFR, fibroblast growth factor receptor; HER, human epidermal growth factor receptor; IGF-1R, insulin-like growth factor-1 receptor; IHC, immunohistochemistry; INPP4B, inositol polyphosphate-4-phosphatase, type II; InsR, insulin receptor; MEK, mitogen-activated protein kinase kinase; mTOR, mammalian target of rapamycin; PARP, poly(ADP-ribose) polymerase; PDK1, phosphoinositide-dependent kinase 1; PH, pleckstrin homology; PI3K, phosphatidylinositol 3-kinase; PIP, phosphatidylinositol 4,5-bisphosphate; $\mathrm{PIP}_{3^{\prime}}$ phosphatidylinositol 3,4,5-trisphosphate; PR, progesterone receptor; PTEN, phosphatase and tensin homolog; RTK, receptor tyrosine kinase; siRNA, small interfering RNA; TNBC, triple-negative breast cancer.

\section{Competing interests}

The authors declare that they have no competing interests.

\section{Acknowledgements}

This work was supported by the National Institutes of Health K99CA142899 (TWM), K08CA143153 (BNR), Breast Cancer Specialized Program of Research Excellence (SPORE) P50CA98131, Vanderbilt-Ingram Cancer Center Support Grant P30CA68485; a grant from the Breast Cancer Research Foundation (CLA); American Cancer Society Clinical Research Professorship Grant CRP-07234 (CLA) and Postdoctoral Fellowship 118813-PF-10-070-01-TBG (JTG); the Department of Defense BC093376 (JTG) and BC087465 (BNR); the Lee Jeans Translational Breast Cancer Research Program (CLA); and Stand Up to Cancer/ American Association for Cancer Research Dream Team Translational Cancer Research Grant SU2C-AACR-DT0209 (CLA).

\section{Author details}

'Department of Cancer Biology, Vanderbilt-Ingram Cancer Center, Vanderbilt University, Nashville, TN 37232, USA. ${ }^{2}$ Breast Cancer Research Program, Vanderbilt-Ingram Cancer Center, Vanderbilt University, Nashville, TN 37232
USA. ${ }^{3}$ Department of Medicine, Vanderbilt-Ingram Cancer Center, Vanderbilt University, Nashville, TN 37232, USA. ${ }^{4}$ Division of Hematology-Oncology, VUMC, 2220 Pierce Avenue, 777 PRB, Nashville, TN 37232, USA.

Published: 1 November 2011

\section{References}

1. Guertin DA, Sabatini DM: Defining the role of mTOR in cancer. Cancer Cell 2007, 12:9-22.

2. Zhao L, Vogt PK: Helical domain and kinase domain mutations in p110alpha of phosphatidylinositol 3-kinase induce gain of function by different mechanisms. Proc Natl Acad Sci U S A 2008, 105:2652-2657.

3. Isakoff SJ, Engelman JA, Irie HY, Luo J, Brachmann SM, Pearline RV, Cantley LC, Brugge JS: Breast cancer-associated PIK3CA mutations are oncogenic in mammary epithelial cells. Cancer Res 2005, 65:10992-11000.

4. Meyer DS, Brinkhaus H, Muller U, Muller M, Cardiff RD, Bentires-Alj M: Luminal expression of PIK3CA mutant H1047R in the mammary gland induces heterogeneous tumors. Cancer Res 2011, 71:4344-4351.

5. Liu P, Cheng H, Santiago S, Raeder M, Zhang F, Isabella A, Yang J, Semaan DJ, Chen C, Fox EA, Gray NS, Monahan J, Schlegel R, Beroukhim R, Mills GB, Zhao JJ: Oncogenic PIK3CA-driven mammary tumors frequently recur via PI3K pathway-dependent and PI3K pathway-independent mechanisms. Nat Med 2011, 17:1116-1120.

6. Perez-Tenorio G, Alkhori L, Olsson B, Waltersson MA, Nordenskjold B, Rutqvist LE, Skoog L, Stal O: PIK3CA mutations and PTEN loss correlate with similar prognostic factors and are not mutually exclusive in breast cancer. Clin Cancer Res 2007, 13:3577-3584.

7. Saal LH, Holm K, Maurer M, Memeo L, Su T, Wang X, Yu JS, Malmström PO, Mansukhani M, Enoksson J, Hibshoosh H, Borg A, Parsons R: PIK3CA mutations correlate with hormone receptors, node metastasis, and ERBB2, and are mutually exclusive with PTEN loss in human breast carcinoma. Cancer Res 2005, 65:2554-2559.

8. Saal LH, Johansson P, Holm K, Gruvberger-Saal SK, She QB, Maurer M, Koujak S, Ferrando AA, Malmström P, Memeo L, Isola J, Bendahl PO, Rosen N, Hibshoosh H, Ringnér M, Borg A, Parsons R: Poor prognosis in carcinoma is associated with a gene expression signature of aberrant PTEN tumor suppressor pathway activity. Proc Natl Acad Sci U S A 2007, 104:7564-7569.

9. Jia S, Roberts TM, Zhao JJ: Should individual PI3 kinase isoforms be targeted in cancer? Curr Opin Cell Biol 2009, 21:199-208.

10. Oda K, Okada J, Timmerman L, Rodriguez-Viciana P, Stokoe D, Shoji K, Taketani Y, Kuramoto H, Knight ZA, Shokat KM, McCormick F: PIK3CA cooperates with other phosphatidylinositol 3'-kinase pathway mutations to effect oncogenic transformation. Cancer Res 2008, 68:8127-8136.

11. Miron A, Varadi M, Carrasco D, Li H, Luongo L, Kim HJ, Park SY, Cho EY, Lewis G, Kehoe S, Iglehart JD, Dillon D, Allred DC, Macconaill L, Gelman R, Polyak K: PIK3CA mutations in in situ and invasive breast carcinomas. Cancer Res 2010, 70:5674-5678.

12. Li H, Zhu R, Wang L, Zhu T, Li Q, Chen Q, Wang H, Zhu H: PIK3CA mutations mostly begin to develop in ductal carcinoma of the breast. Exp Mol Pathol 2010, 88:150-155.

13. Dunlap J, Le C, Shukla A, Patterson J, Presnell A, Heinrich MC, Corless CL, Troxell ML: Phosphatidylinositol-3-kinase and AKT1 mutations occur early in breast carcinoma. Breast Cancer Res Treat 2010, 120:409-418.

14. Kalinsky K, Heguy A, Bhanot UK, Patil S, Moynahan ME: PIK3CA mutations rarely demonstrate genotypic intratumoral heterogeneity and are selected for in breast cancer progression. Breast Cancer Res Treat 2011, 129:635-643.

15. Folkes AJ, Ahmadi K, Alderton WK, Alix S, Baker SJ, Box G, Chuckowree IS Clarke PA, Depledge P, Eccles SA, Friedman LS, Hayes A, Hancox TC, Kugendradas A, Lensun L, Moore P, Olivero AG, Pang J, Patel S, Pergl-Wilson GH, Raynaud FI, Robson A, Saghir N, Salphati L, Sohal S, Ultsch MH, Valenti M, Wallweber HJ, Wan NC, Wiesmann C, et al:: The identification of 2-(1Hindazol-4-yl)-6-(4-methanesulfonyl-piperazin-1-ylmethyl)-4-morpholin-4yl-thieno[3,2-d]pyrimidine (GDC-0941) as a potent, selective, orally bioavailable inhibitor of class I PI3 kinase for the treatment of cancer. J Med Chem 2008, 51:5522-5532.

16. Maira SM, Stauffer F, Brueggen J, Furet P, Schnell C, Fritsch C, Brachmann S, Chène P, De Pover A, Schoemaker K, Fabbro D, Gabriel D, Simonen M, Murphy L, Finan P, Sellers W, García-Echeverría C: Identification and characterization of NVP-BEZ235, a new orally available dual phosphatidylinositol 3-kinase/ mammalian target of rapamycin inhibitor with potent in vivo antitumor 
activity. Mol Cancer Ther 2008, 7:1851-1863.

17. Chandarlapaty S, Sawai A, Scaltriti M, Rodrik-Outmezguine V, Grbovic-Huezo O, Serra V, Majumder PK, Baselga J, Rosen N: AKT inhibition relieves feedback suppression of receptor tyrosine kinase expression and activity. Cancer Cell 2011, 19:58-71.

18. Rhodes N, Heerding DA, Duckett DR, Eberwein DJ, Knick VB, Lansing TJ, McConnell RT, Gilmer TM, Zhang SY, Robell K, Kahana JA, Geske RS, Kleymenova EV, Choudhry AE, Lai Z, Leber JD, Minthorn EA, Strum SL, Wood ER, Huang PS, Copeland RA, Kumar R: Characterization of an Akt kinase inhibitor with potent pharmacodynamic and antitumor activity. Cancer Res 2008, 68:2366-2374

19. Hirai H, Sootome H, Nakatsuru Y, Miyama K, Taguchi S, Tsujioka K, Ueno Y, Hatch H, Majumder PK, Pan BS, Kotani H: MK-2206, an allosteric Akt inhibitor, enhances antitumor efficacy by standard chemotherapeutic agents or molecular targeted drugs in vitro and in vivo. Mol Cancer Ther 2010, 9:1956-1967.

20. Dowling RJ, Topisirovic I, Fonseca BD, Sonenberg N: Dissecting the role of mTOR: lessons from mTOR inhibitors. Biochim Biophys Acta 2010, 1804:433-439

21. Bhagwat SV, Gokhale PC, Crew AP, Cooke A, Yao Y, Mantis C, Kahler J, Workman J, Bittner M, Dudkin L, Epstein DM, Gibson NW, Wild R, Arnold LD, Houghton PJ, Pachter JA: Preclinical characterization of OSI-027, a potent and selective inhibitor of mTORC1 and mTORC2: distinct from rapamycin Mol Cancer Ther 2011, 10:1394-1406.

22. Miller TW, Forbes JT, Shah C, Wyatt SK, Manning HC, Olivares MG, Sanchez V, Dugger TC, de Matos Granja N, Narasanna A, Cook RS, Kennedy JP, Lindsley CW, Arteaga CL: Inhibition of mammalian target of rapamycin is required for optimal antitumor effect of HER2 inhibitors against HER2overexpressing cancer cells. Clin Cancer Res 2009, 15:7266-7276.

23. O'Reilly KE, Rojo F, She QB, Solit D, Mills GB, Smith D, Lane H, Hofmann F Hicklin DJ, Ludwig DL, Baselga J, Rosen N: mTOR inhibition induces upstream receptor tyrosine kinase signaling and activates Akt. Cancer Res 2006, 66:1500-1508

24. Carracedo A, Ma L, Teruya-Feldstein J, Rojo F, Salmena L, Alimonti A, Egia A, Sasaki AT, Thomas G, Kozma SC, Papa A, Nardella C, Cantley LC, Baselga Pandolf PP: Inhibition of mTORC1 leads to MAPK pathway activation through a PI3K-dependent feedback loop in human cancer. J Clin Invest 2008, 118:3065-3074

25. Chakrabarty A, Sanchez V, Kuba MG, Rinehart C, Arteaga CL: Feedback upregulation of HER3 (ErbB3) expression and activity attenuates antitumor effect of PI3K inhibitors. Proc Natl Acad Sci U S A 2011 [Epub ahead of print].

26. Garrett JT, Olivares MG, Rinehart C, Granja-Ingram ND, Sánchez V, Chakrabarty A, Dave B, Cook RS, Pao W, McKinely E, Manning HC, Chang J, Arteaga CL: Transcriptional and posttranslational up-regulation of HER3 (ErbB3) compensates for inhibition of the HER2 tyrosine kinase. Proc Natl Acad Sci USA 2011, 108:5021-5026.

27. Amin DN, Sergina N, Ahuja D, McMahon M, Blair JA, Wang D, Hann B, Koch KM, Shokat KM, Moasser MM: Resiliency and vulnerability in the HER2-HER3 tumorigenic driver. Sci TransI Med 2011, 2:16ra17.

28. Early Breast Cancer Trialists' Collaborative Group: Effects of chemotherapy and hormonal therapy for early breast cancer on recurrence and 15-year survival: an overview of the randomised trials. Lancet 2005, 365:1687-1717.

29. Forbes JF, Cuzick J, Buzdar A, Howell A, Tobias JS, Baum M: Effect of anastrozole and tamoxifen as adjuvant treatment for early-stage breast cancer: 100-month analysis of the ATAC trial. Lancet Oncol 2008, 9:45-53.

30. Ellis MJ, Tao Y, Young O, White S, Proia AD, Murray J, Renshaw L, Faratian D, Thomas J, Dowsett M, Krause A, Evans DB, Miller WR, Dixon JM: Estrogenindependent proliferation is present in estrogen-receptor HER2-positive primary breast cancer after neoadjuvant letrozole. J Clin Oncol 2006, 24:3019-3025

31. Arpino G, Green SJ, Allred DC, Lew D, Martino S, Osborne CK, Elledge RM: HER-2 amplification, HER-1 expression, and tamoxifen response in estrogen receptor-positive metastatic breast cancer: a southwest oncology group study. Clin Cancer Res 2004, 10:5670-5676.

32. De Laurentiis M, Arpino G, Massarelli E, Ruggiero A, Carlomagno C, Ciardiello F, Tortora G, D'Agostino D, Caputo F, Cancello G, Montagna E, Malorni L, Zinno L, Lauria R, Bianco AR, De Placido S: A meta-analysis on the interaction between HER-2 expression and response to endocrine treatment in advanced breast cancer. Clin Cancer Res 2005, 11:4741-4748.

33. Campbell RA, Bhat-Nakshatri P, Patel NM, Constantinidou D, Ali S, Nakshatri H:
Phosphatidylinositol 3-kinase/AKT-mediated activation of estrogen receptor alpha: a new model for anti-estrogen resistance. J Biol Chem 2001 276:9817-9824

34. Yamnik RL, Digilova A, Davis DC, Brodt ZN, Murphy CJ, Holz MK: S6 kinase 1 regulates estrogen receptor alpha in control of breast cancer cell proliferation. J Biol Chem 2009, 284:6361-6369.

35. Coso OA, Chiariello M, Yu JC, Teramoto H, Crespo P, Xu N, Miki T, Gutkind JS: The small GTP-binding proteins Rac1 and $\mathrm{Cdc} 42$ regulate the activity of the JNK/SAPK signaling pathway. Cell 1995, 81:1137-1146.

36. Minden A, Lin A, Claret FX, Abo A, Karin M: Selective activation of the JNK signaling cascade and c-Jun transcriptional activity by the small GTPases Rac and Cdc42Hs. Cell 1995, 81:1147-1157.

37. Logan SK, Falasca M, Hu P, Schlessinger J: Phosphatidylinositol 3-kinase mediates epidermal growth factor-induced activation of the c-Jun N-terminal kinase signaling pathway. Mol Cell Biol 1997, 17:5784-5790.

38. Hibi M, Lin A, Smeal T, Minden A, Karin M: Identification of an oncoproteinand UV-responsive protein kinase that binds and potentiates the c-Jun activation domain. Genes Dev 1993, 7:2135-2148.

39. Derijard B, Hibi M, Wu IH, Barrett T, Su B, Deng T, Karin M, Davis RJ: JNK1: a protein kinase stimulated by UV light and Ha-Ras that binds and phosphorylates the c-Jun activation domain. Cell 1994, 76:1025-1037.

40. Rauscher FJ, 3rd, Cohen DR, Curran T, Bos TJ, Vogt PK, Bohmann D, Tjian R, Franza BR, Jr.: Fos-associated protein p39 is the product of the jun proto-oncogene. Science 1988, 240:1010-1016.

41. DeNardo DG, Cuba VL, Kim H, Wu K, Lee AV, Brown PH: Estrogen receptor DNA binding is not required for estrogen-induced breast cell growth. Mol Cell Endocrinol 2007, 277:13-25.

42. Petz LN, Ziegler YS, Loven MA, Nardulli AM: Estrogen receptor alpha and activating protein-1 mediate estrogen responsiveness of the progesterone receptor gene in MCF-7 breast cancer cells. Endocrinology 2002, 143:4583-4591.

43. Massarweh S, Schiff R: Unraveling the mechanisms of endocrine resistance in breast cancer: new therapeutic opportunities. Clin Cancer Res 2007, 13:1950-1954

44. Shou J, Massarweh S, Osborne CK, Wakeling AE, Ali S, Weiss H, Schiff R: Mechanisms of tamoxifen resistance: increased estrogen receptor-HER2/ neu cross-talk in ER/HER2-positive breast cancer. J Natl Cancer Inst 2004, 96:926-935.

45. Hurtado A, Holmes KA, Geistlinger TR, Hutcheson IR, Nicholson RI, Brown M, Jiang J, Howat WJ, Ali S, Carroll JS: Regulation of ERBB2 by oestrogen receptor-PAX2 determines response to tamoxifen. Nature 2008, 456:663-666

46. Mukku VR, Stancel GM: Regulation of epidermal growth factor receptor by estrogen. J Biol Chem 1985, 260:9820-9824.

47. Krywicki RF, Figueroa JA, Jackson JG, Kozelsky TW, Shimasaki S, Von Hoff DD, Yee D: Regulation of insulin-like growth factor binding proteins in ovarian cancer cells by oestrogen. Eur J Cancer 1993, 29A:2015-2019.

48. Martinez-Lacaci I, Saceda M, Plowman GD, Johnson GR, Normanno N, Salomon DS, Dickson RB: Estrogen and phorbol esters regulate amphiregulin expression by two separate mechanisms in human breast cancer cell lines. Endocrinology 1995, 136:3983-3992.

49. Guvakova MA, Surmacz E: Tamoxifen interferes with the insulin-like growth factor I receptor (IGF-IR) signaling pathway in breast cancer cells. Cancer Res 1997, 57:2606-2610.

50. Lee AV, Jackson JG, Gooch JL, Hilsenbeck SG, Coronado-Heinsohn E, Osborne $C K$, Yee D: Enhancement of insulin-like growth factor signaling in human breast cancer: estrogen regulation of insulin receptor substrate-1 expression in vitro and in vivo. Mol Endocrinol 1999, 13:787-796.

51. Generali D, Fox SB, Brizzi MP, Allevi G, Bonardi S, Aguggini S, Milani M, Bersiga A, Campo L, Dionisio R, Vergoni F, Giardini R, Dogliotti L, Bottini A, Harris AL, Berruti A: Down-regulation of phosphatidylinositol 3'-kinase/AKT/ molecular target of rapamycin metabolic pathway by primary letrozolebased therapy in human breast cancer. Clin Cancer Res 2008, 14:2673-2680.

52. Baselga J, Semiglazov V, van Dam P, Manikhas A, Bellet M, Mayordomo J, Campone M, Kubista E, Greil R, Bianchi G, Steinseifer J, Molloy B, Tokaji E, Gardner H, Phillips P, Stumm M, Lane HA, Dixon JM, Jonat W, Rugo HS: Phase II randomized study of neoadjuvant everolimus plus letrozole compared with placebo plus letrozole in patients with estrogen receptor-positive breast cancer. J Clin Oncol 2009, 27:2630-2637.

53. Simoncini T, Hafezi-Moghadam A, Brazil DP, Ley K, Chin WW, Liao JK: Interaction of oestrogen receptor with the regulatory subunit of 
phosphatidylinositol-3-OH kinase. Nature 2000, 407:538-541.

54. Miller TW, Pérez-Torres M, Narasanna A, Guix M, Stål O, Pérez-Tenorio G, Gonzalez-Angulo AM, Hennessy BT, Mills GB, Kennedy JP, Lindsley CW, Arteaga CL: Loss of Phosphatase and Tensin homologue deleted on chromosome 10 engages ErbB3 and insulin-like growth factor-I receptor signaling to promote antiestrogen resistance in breast cancer. Cancer Res 2009, 69:4192-4201.

55. Song RX, McPherson RA, Adam L, Bao Y, Shupnik M, Kumar R, Santen RJ: Linkage of rapid estrogen action to MAPK activation by ERalpha-Shc association and Shc pathway activation. Mol Endocrinol 2002, 16:116-127.

56. Song RX, Fan P, Yue W, Chen Y, Santen RJ: Role of receptor complexes in the extranuclear actions of estrogen receptor alpha in breast cancer. Endocr Relat Cancer 2006, 13 Suppl 1:S3-13.

57. Massarweh S, Osborne CK, Creighton CJ, Qin L, Tsimelzon A, Huang S, Weiss $H$, Rimawi M, Schiff R: Tamoxifen resistance in breast tumors is driven by growth factor receptor signaling with repression of classic estrogen receptor genomic function. Cancer Res 2008, 68:826-833.

58. Miller TW, Hennessy BT, Gonzalez-Angulo AM, Fox EM, Mills GB, Chen H, Higham C, Garcia-Echeverria C, Shyr Y, Arteaga CL: Hyperactivation of phosphatidylinositol-3 kinase promotes escape from hormone dependence in estrogen receptor-positive human breast cancer. J Clin Invest 2010, 120:2406-2413

59. Fan M, Yan PS, Hartman-Frey C, Chen L, Paik H, Oyer SL, Salisbury JD, Cheng AS, Li L, Abbosh PH, Huang TH, Nephew KP: Diverse gene expression and DNA methylation profiles correlate with differential adaptation of breast cancer cells to the antiestrogens tamoxifen and fulvestrant. Cancer Res 2006, 66:11954-11966.

60. Frogne T, Benjaminsen RV, Sonne-Hansen K, Sorensen BS, Nexo E, Laenkholm AV, Rasmussen LM, Riese DJ 2nd, de Cremoux P, Stenvang J, Lykkesfeldt AE: Activation of ErbB3, EGFR and Erk is essential for growth of human breast cancer cell lines with acquired resistance to fulvestrant. Breast Cancer Res Treat 2009, 114:263-275.

61. Massarweh S, Osborne CK, Jiang S, Wakeling AE, Rimawi M, Mohsin SK, Hilsenbeck S, Schiff R: Mechanisms of tumor regression and resistance to estrogen deprivation and fulvestrant in a model of estrogen receptorpositive, HER-2/neu-positive breast cancer. Cancer Res 2006, 66:8266-8273.

62. Crowder RJ, Phommaly C, Tao Y, Hoog J, Luo J, Perou CM, Parker JS, Miller MA, Huntsman DG, Lin L, Snider J, Davies SR, Olson JA Jr, Watson MA, Saporita A, Weber JD, Ellis MJ: PIK3CA and PIK3CB inhibition produce synthetic lethality when combined with estrogen deprivation in estrogen receptorpositive breast cancer. Cancer Res 2009, 69:3955-3962.

63. Turner N, Pearson A, Sharpe R, Lambros M, Geyer F, Lopez-Garcia MA, Natrajan R, Marchio C, lorns E, Mackay A, Gillett C, Grigoriadis A, Tutt A, Reis-Filho JS, Ashworth A: FGFR1 amplification drives endocrine therapy resistance and is a therapeutic target in breast cancer. Cancer Res 2010, 70:2085-2094.

64. Gewinner C, Wang ZC, Richardson A, Teruya-Feldstein J, Etemadmoghadam D, Bowtell D, Barretina J, Lin WM, Rameh L, Salmena L, Pandolf PP, Cantley LC: Evidence that inositol polyphosphate 4-phosphatase type II is a tumor suppressor that inhibits PI3K signaling. Cancer Cell 2009, 16:115-125.

65. Loi S, Haibe-Kains B, Majjaj S, Lallemand F, Durbecq V, Larsimont D, GonzalezAngulo AM, Pusztai L, Symmans WF, Bardelli A, Ellis P, Tutt AN, Gillett CE, Hennessy BT, Mills GB, Phillips WA, Piccart MJ, Speed TP, McArthur GA, Sotiriou C: PIK3CA mutations associated with gene signature of low mTORC1 signaling and better outcomes in estrogen receptor-positive breast cancer. Proc Natl Acad SciU S A 2010, 107:10208-10213.

66. Stemke-Hale K, Gonzalez-Angulo AM, Lluch A, Neve RM, Kuo WL, Davies M, Carey M, Hu Z, Guan Y, Sahin A, Symmans WF, Pusztai L, Nolden LK, Horlings H, Berns K, Hung MC, van de Vijver MJ, Valero V, Gray JW, Bernards R, Mills GB, Hennessy BT: An integrative genomic and proteomic analysis of PIK3CA, PTEN, and AKT mutations in breast cancer. Cancer Res 2008, 68:6084-6091.

67. Ellis MJ, Lin L, Crowder R, Tao Y, Hoog J, Snider J, Davies S, DeSchryver K, Evans DB, Steinseifer J, Bandaru R, Liu W, Gardner H, Semiglazov V, Watson M, Hunt K, Olson J, Baselga J: Phosphatidyl-inositol-3-kinase alpha catalytic subunit mutation and response to neoadjuvant endocrine therapy for estrogen receptor positive breast cancer. Breast Cancer Res Treat 2010, 119:379-390.

68. Campbell IG, Russell SE, Choong DY, Montgomery KG, Ciavarella ML, Hooi CS, Cristiano BE, Pearson RB, Phillips WA: Mutation of the PIK3CA gene in ovarian and breast cancer. Cancer Res 2004, 64:7678-7681

69. Miller TW, Balko JM, Fox EM, Ghazoui Z, Dunbier A, Anderson H, Dowsett M, Jiang A, Smith RA, Maira S-M, Manning HC, González-Angulo AM, Mills GB, Higham C, Chanthaphaychith S, Kuba MG, Miller WR, Shyr Y, Arteaga CL:
ERa-dependent E2F transcription can mediate resistance to estrogen deprivation in human breast cancer. Cancer Discovery 2011, 1:338-351.

70. Sotiriou C, Pusztai L: Gene-expression signatures in breast cancer. NEnglJ Med 2009, 360:790-800.

71. Creighton CJ, Fu X, Hennessy BT, Casa AJ, Zhang Y, Gonzalez-Angulo AM, Lluch A, Gray JW, Brown PH, Hilsenbeck SG, Osborne CK, Mills GB, Lee AV, $S c h i f f$ : Proteomic and transcriptomic profiling reveals a link between the PI3K pathway and lower estrogen receptor (ER) levels and activity in ER+ breast cancer. Breast Cancer Res 2010, 12:R40.

72. Sørlie T, Perou CM, Tibshirani R, Aas T, Geisler S, Johnsen H, Hastie T, Eisen MB, van de Rijn M, Jeffrey SS, Thorsen T, Quist H, Matese JC, Brown PO, Botstein D, Eystein Lønning P, Børresen-Dale AL: Gene expression patterns of breast carcinomas distinguish tumor subclasses with clinical implications. Proc Natl Acad Sci U S A 2001, 98:10869-10874

73. Bachelot T, Bourgier C, Cropet C, Guastalla J-P, Ferrero J-M, Leger-Falandry C, Soulie P, Eymard J-C, Debled M, Spaeth D, Legouffe E, Delozier T, El Kouri C, Chidiac J: TAMRAD: A GINECO randomized phase II trial of everolimus in combination with tamoxifen versus tamoxifen alone in patients (pts) with hormone-receptor positive, HER2 negative metastatic breast cancer (MBC) with prior exposure to aromatase inhibitors (Al). Cancer Res 2010, 70(24S):Abstract S1-6.

74. Baselga J: Everolimus in combination with exemestane for postmenopausal women with advanced breast cancer who are refractory to letrozole or anastrozole: results of the BOLERO-2 phase III trial. European Multidisciplinary Cancer Congress Presentation of late breaking abstract No 9LBA September 26, 20112011.

75. Munzone E, Curigliano G, Rocca A, Bonizzi G, Renne G, Goldhirsch A, Nole F: Reverting estrogen-receptor-negative phenotype in HER-2overexpressing advanced breast cancer patients exposed to trastuzumab plus chemotherapy. Breast Cancer Res 2006, 8:R4.

76. Xia W, Bacus S, Hegde P, Husain I, Strum J, Liu L, Paulazzo G, Lyass L, Trusk P, Hill J, Harris J, Spector NL: A model of acquired autoresistance to a potent ErbB2 tyrosine kinase inhibitor and a therapeutic strategy to prevent its onset in breast cancer. Proc Natl Acad Sci U S A 2006, 103:7795-7800,

77. Johnston S, Pippen J Jr, Pivot X, Lichinitser M, Sadeghi S, Dieras V, Gomez HL, Romieu G, Manikhas A, Kennedy MJ, Press MF, Maltzman J, Florance A, O'Rourke L, Oliva C, Stein S, Pegram M: Lapatinib combined with letrozole versus letrozole and placebo as first-line therapy for postmenopausal hormone receptor-positive metastatic breast cancer. J Clin Oncol 2009, 27:5538-5546.

78. Kaufman B, Mackey JR, Clemens MR, Bapsy PP, Vaid A, Wardley A, Tjulandin S, Jahn M, Lehle M, Feyereislova A, Révil C, Jones A: Trastuzumab plus anastrozole versus anastrozole alone for the treatment of postmenopausal women with human epidermal growth factor receptor 2-positive, hormone receptor-positive metastatic breast cancer: results from the randomized phase III TAnDEM study. J Clin Oncol 2009, 27:5529-5537.

79. Cobleigh MA, Vogel CL, Tripathy D, Robert NJ, Scholl S, Fehrenbacher L, Wolter JM, Paton V, Shak S, Lieberman G, Slamon DJ: Multinational study of the efficacy and safety of humanized anti-HER2 monoclonal antibody in women who have HER2-overexpressing metastatic breast cancer that has progressed after chemotherapy for metastatic disease. J Clin Oncol 1999, 17:2639-2648.

80. Blackwell KL, Burstein HJ, Storniolo AM, Rugo H, Sledge G, Koehler M, Ellis C, Casey M, Vukelja S, Bischoff J, Baselga J, O'Shaughnessy J: Randomized study of Lapatinib alone or in combination with trastuzumab in women with ErbB2-positive, trastuzumab-refractory metastatic breast cancer. J Clin Oncol 2010, 28:1124-1130.

81. Cameron D, Casey M, Press M, Lindquist D, Pienkowski T, Romieu CG, Chan S, Jagiello-Gruszfeld A, Kaufman B, Crown J, Chan A, Campone M, Viens P, Davidson N, Gorbounova V, Raats Jl, Skarlos D, Newstat B, Roychowdhury D, Paoletti P, Oliva C, Rubin S, Stein S, Geyer CE: A phase III randomized comparison of lapatinib plus capecitabine versus capecitabine alone in women with advanced breast cancer that has progressed on trastuzumab: updated efficacy and biomarker analyses. Breast Cancer Res Treat 2008, 112:533-543.

82. Eichhorn PJ, Gili M, Scaltriti M, Serra V, Guzman M, Nijkamp W, Beijersbergen RL, Valero V, Seoane J, Bernards R, Baselga J: Phosphatidylinositol 3-kinase hyperactivation results in lapatinib resistance that is reversed by the mTOR/phosphatidylinositol 3-kinase inhibitor NVP-BEZ235. Cancer Res 2008, 68:9221-9230. 
83. Rexer BN, Ham AJ, Rinehart C, Hill S, de Matos Granja-Ingram N, GonzálezAngulo AM, Mills GB, Dave B, Chang JC, Liebler DC, Arteaga CL: Phosphoproteomic mass spectrometry profiling links Src family kinases to escape from HER2 tyrosine kinase inhibition. Oncogene 2011, 30:4163-4174.

84. Esteva FJ, Guo H, Zhang S, Santa-Maria C, Stone S, Lanchbury JS, Sahin AA, Hortobagyi GN, Yu D: PTEN, PIK3CA, p-AKT, and p-p70S6K status: association with trastuzumab response and survival in patients with HER2-positive metastatic breast cancer. Am J Pathol 2010, 177:1647-1656.

85. Razis E, Bobos M, Kotoula V, Eleftheraki AG, Kalofonos HP, Pavlakis K, Papakostas P, Aravantinos G, Rigakos G, Efstratiou I, Petraki K, Bafaloukos D, Kostopoulos I, Pectasides D, Kalogeras KT, Skarlos D, Fountzilas G: Evaluation of the association of PIK3CA mutations and PTEN loss with efficacy of trastuzumab therapy in metastatic breast cancer. Breast Cancer Res Treat 2011, 128:447-456.

86. Berns K, Horlings HM, Hennessy BT, Madiredjo M, Hijmans EM, Beelen K, Linn SC, Gonzalez-Angulo AM, Stemke-Hale K, Hauptmann M, Beijersbergen RL, Mills GB, van de Vijver MJ, Bernards R: A functional genetic approach identifies the PI3K pathway as a major determinant of trastuzumab resistance in breast cancer. Cancer Cell 2007, 12:395-402.

87. Wang L, Zhang Q, Zhang J, Sun S, Guo H, Jia Z, Wang B, Shao Z, Wang Z, Hu X: PI3K pathway activation results in low efficacy of both trastuzumab and lapatinib. BMC Cancer 2011, 11:248.

88. Dave B, Migliaccio I, Gutierrez MC, Wu MF, Chamness GC, Wong H, Narasanna A, Chakrabarty A, Hilsenbeck SG, Huang J, Rimawi M, Schiff R, Arteaga C, Osborne CK, Chang JC: Loss of phosphatase and tensin homolog or phosphoinositol-3 kinase activation and response to trastuzumab or lapatinib in human epidermal growth factor receptor 2-overexpressing locally advanced breast cancers. J Clin Oncol 2011, 29:166-173.

89. Morrow PH, Wulf GM, Booser DJ, Moore JA, Flores PR, Krop IE, Winer EP, Hortobagyi GN, Yu D, Esteva FJ: Phase I/II trial of everolimus (RAD001) and trastuzumab in patients with trastuzumab-resistant, HER2-overexpressing breast cancer. J Clin Oncol 2010, 28(15s):abstract 1014.

90. Jerusalem G, Fasolo A, Dieras V, Cardoso F, Bergh J, Vittori L, Zhang Y, Massacesi C, Sahmoud T, Gianni L: Phase I trial of oral mTOR inhibitor everolimus in combination with trastuzumab and vinorelbine in pretreated patients with HER2-overexpressing metastatic breast cancer. Breast Cancer Res Treat 2011, 125:447-455.

91. Andre F, Campone M, O'Regan R, Manlius C, Massacesi C, Sahmoud T, Mukhopadhyay P, Soria JC, Naughton M, Hurvitz SA: Phase I study of everolimus plus weekly paclitaxel and trastuzumab in patients with metastatic breast cancer pretreated with trastuzumab. J Clin Oncol 2010, 28:5110-5115.

92. Serra V, Scaltriti M, Prudkin L, Eichhorn PJ, Ibrahim YH, Chandarlapaty S, Markman B, Rodriguez O, Guzman M, Rodriguez S, Gili M, Russillo M, Parra JL, Singh S, Arribas J, Rosen N, Baselga J: PI3K inhibition results in enhanced HER signaling and acquired ERK dependency in HER2-overexpressing breast cancer. Oncogene 2011, 30:2547-2557.

93. Reddy KB: Triple-negative breast cancers: an updated review on treatment options. Curr Oncol 2011, 18:e173-179.

94. Lehmann BD, Bauer JA, Chen X, Sanders ME, Chakravarthy AB, Shyr Y, Pietenpol JA: Identification of human triple-negative breast cancer subtypes and preclinical models for selection of targeted therapies. J Clin Invest 2011, 121:2750-2767.

95. Saal LH, Gruvberger-Saal SK, Persson C, Lövgren K, Jumppanen M, Staaf J, Jönsson G, Pires MM, Maurer M, Holm K, Koujak S, Subramaniyam S, VallonChristersson J, Olsson H, Su T, Memeo L, Ludwig T, Ethier SP, Krogh M, Szabolcs M, Murty W, Isola J, Hibshoosh H, Parsons R, Borg A: Recurrent gross mutations of the PTEN tumor suppressor gene in breast cancers with deficient DSB repair. Nat Genet 2008, 40:102-107.

96. Mendes-Pereira AM, Martin SA, Brough R, McCarthy A, Taylor JR, Kim JS, Waldman T, Lord CJ, Ashworth A: Synthetic lethal targeting of PTEN mutant cells with PARP inhibitors. EMBO Mol Med 2009, 1:315-322

97. Farmer H, MCCabe N, Lord CJ, Tutt AN, Johnson DA, Richardson TB, Santarosa M, Dillon KJ, Hickson I, Knights C, Martin NM, Jackson SP, Smith GC, Ashworth A: Targeting the DNA repair defect in BRCA mutant cells as a therapeutic strategy. Nature 2005, 434:917-921.

98. Bozulic L, Surucu B, Hynx D, Hemmings BA: PKBalpha/Akt1 acts downstream of DNA-PK in the DNA double-strand break response and promotes survival. Mol Cell 2008, 30:203-213.

99. Hu L, Hofmann J, Lu Y, Mills GB, Jaffe RB: Inhibition of phosphatidylinositol 3 '-kinase increases efficacy of paclitaxel in in vitro and in vivo ovarian cancer models. Cancer Res 2002, 62:1087-1092

100. Ng SSW, Tsao MS, Chow S, Hedley DW: Inhibition of phosphatidylinositide 3-kinase enhances gemcitabine-induced apoptosis in human pancreatic cancer cells. Cancer Res 2000, 60:5451-5455.

101. Westhoff MA, Kandenwein JA, Karl S, Vellanki SH, Braun V, Eramo A, Antoniadis G, Debatin KM, Fulda S: The pyridinylfuranopyrimidine inhibitor, PI-103, chemosensitizes glioblastoma cells for apoptosis by inhibiting DNA repair. Oncogene 2009, 28:3586-3596.

102. Wallin JJ, Guan J, Prior WW, Edgar KA, Kassees R, Sampath D, Belvin M, Friedman LS: Nuclear phospho-Akt increase predicts synergy of PI3K inhibition and doxorubicin in breast and ovarian cancer. Sci Trans/Med 2010, 2:48ra66.

103. Janku F, Tsimberidou AM, Garrido-Laguna I, Wang X, Luthra R, Hong DS, Naing A, Falchook GS, Moroney JW, Piha-Paul SA, Wheler JJ, Moulder SL, Fu S, Kurzrock R: PIK3CA mutations in patients with advanced cancers treated with PI3K/AKT/mTOR axis inhibitors. Mol Cancer Ther 2011, 10:558-565.

104. Shoman N, Klassen S, McFadden A, Bickis MG, Torlakovic E, Chibbar R: Reduced PTEN expression predicts relapse in patients with breast carcinoma treated by tamoxifen. Mod Pathol 2005, 18:250-259.

105. Gonzalez-Angulo AM, Ferrer-Lozano J, Stemke-Hale K, Sahin A, Liu S, Barrera JA, Burgues O, Lluch AM, Chen H, Hortobagyi GN, Mills GB, Meric-Bernstam F: PI3K pathway mutations and PTEN levels in primary and metastatic breast cancer. Mol Cancer Ther 2011, 10:1093-1101.

106. Hennessy BT, Gonzalez-Angulo AM, Stemke-Hale K, Gilcrease MZ, Krishnamurthy S, Lee JS, Fridlyand J, Sahin A, Agarwal R, Joy C, Liu W, Stivers D, Baggerly K, Carey M, Lluch A, Monteagudo C, He X, Weigman V, Fan C, Palazzo J, Hortobagyi GN, Nolden LK, Wang NJ, Valero V, Gray JW, Perou CM, Mills GB: Characterization of a naturally occurring breast cancer subset enriched in epithelial-to-mesenchymal transition and stem cell characteristics. Cancer Res 2009, 69:4116-4124.

107. Samuels Y, Wang Z, Bardelli A, Silliman N, Ptak J, Szabo S, Yan H, Gazdar A Powell SM, Riggins GJ, Willson JK, Markowitz S, Kinzler KW, Vogelstein B, Velculescu VE: High frequency of mutations of the PIK3CA gene in human cancers. Science 2004, 304:554.

108. Law JH, Habibi G, Hu K, Masoudi H, Wang MY, Stratford AL, Park E, Gee JM, Finlay P, Jones HE, Nicholson RI, Carboni J, Gottardis M, Pollak M, Dunn SE: Phosphorylated insulin-like growth factor-i/insulin receptor is present in all breast cancer subtypes and is related to poor survival. Cancer Res 2008, 68:10238-10246.

109. Fu P, Ibusuki M, Yamamoto Y, Hayashi M, Murakami K, Zheng S, Iwase H: Insulin-like growth factor-1 receptor gene expression is associated with survival in breast cancer: a comprehensive analysis of gene copy number, mRNA and protein expression. Breast Cancer Res Treat 2011, 130:307-317.

110. Elbauomy Elsheikh S, Green AR, Lambros MB, Turner NC, Grainge MJ, Powe D, Ellis IO, Reis-Filho JS: FGFR1 amplification in breast carcinomas: a chromogenic in situ hybridisation analysis. Breast Cancer Res 2007, 9:R23.

111. Monni O, Barlund M, Mousses S, Kononen J, Sauter G, Heiskanen M, Paavola P, Avela K, Chen Y, Bittner ML, Kallioniemi A: Comprehensive copy number and gene expression profiling of the 17q23 amplicon in human breast cancer. Proc Natl Acad Sci U S A 2001, 98:5711-5716.

112. Fedele CG, Ooms LM, Ho M, Vieusseux J, O'Toole SA, Millar EK, Lopez-Knowles E, Sriratana A, Gurung R, Baglietto L, Giles GG, Bailey CG, Rasko JE, Shields BJ, Price JT, Majerus PW, Sutherland RL, Tiganis T, McLean CA, Mitchell CA: Inositol polyphosphate 4-phosphatase II regulates PI3K/Akt signaling and is lost in human basal-like breast cancers. Proc Natl Acad Sci U S A 2010, 107:22231-22236.

113. Jaiswal BS, Janakiraman V, Kljavin NM, Chaudhuri S, Stern HM, Wang W, Kan Z, Dbouk HA, Peters BA, Waring P, Dela Vega T, Kenski DM, Bowman KK, Lorenzo M, Li H, Wu J, Modrusan Z, Stinson J, Eby M, Yue P, Kaminker JS, de Sauvage FJ, Backer JM, Seshagiri S: Somatic mutations in p85alpha promote tumorigenesis through class IA PI3K activation. Cancer Cell 2009, 16:463-474.

114. Carpten JD, Faber AL, Horn C, Donoho GP, Briggs SL, Robbins CM, Hostetter G, Boguslawski S, Moses TY, Savage S, Uhlik M, Lin A, Du J, Qian YW, Zeckner DJ, Tucker-Kellogg G, Touchman J, Patel K, Mousses S, Bittner M, Schevitz R, Lai $\mathrm{MH}$, Blanchard KL, Thomas JE: A transforming mutation in the pleckstrin homology domain of AKT1 in cancer. Nature 2007, 448:439-444.

115. Bellacosa A, de Feo D, Godwin AK, Bell DW, Cheng JQ, Altomare DA, Wan M, Dubeau L, Scambia G, Masciullo V, Ferrandina G, Benedetti Panici P, Mancuso S, Neri G, Testa JR: Molecular alterations of the AKT2 oncogene in ovarian and breast carcinomas. Int J Cancer 1995, 64:280-285. 
116. Al-Kuraya K, Schraml P, Torhorst J, Tapia C, Zaharieva B, Novotny H, Spichtin H, Maurer R, Mirlacher M, Köchli O, Zuber M, Dieterich H, Mross F, Wilber K, Simon R, Sauter G: Prognostic relevance of gene amplifications and coamplifications in breast cancer. Cancer Res 2004, 64:8534-8540.

117. Maurer M, Su T, Saal LH, Koujak S, Hopkins BD, Barkley CR, Wu J, Nandula S, Dutta B, Xie Y, Chin YR, Kim DI, Ferris JS, Gruvberger-Saal SK, Laakso M, Wang X, Memeo L, Rojtman A, Matos T, Yu JS, Cordon-Cardo C, Isola J, Terry MB, Toker A, Mills GB, Zhao JJ, Murty W, Hibshoosh H, Parsons R: 3-Phosphoinositide-dependent kinase 1 potentiates upstream lesions on the phosphatidylinositol 3-kinase pathway in breast carcinoma. Cancer Res 2009, 69:6299-6306.

118. Rochlitz CF, Scott GK, Dodson JM, Liu E, Dollbaum C, Smith HS, Benz CC: Incidence of activating ras oncogene mutations associated with primary and metastatic human breast cancer. Cancer Res 1989, 49:357-360.
119. Di Nicolantonio F, Arena S, Tabernero J, Grosso S, Molinari F, Macarulla T, Russo M, Cancelliere C, Zecchin D, Mazzucchelli L, Sasazuki T, Shirasawa S, Geuna M, Frattini M, Baselga J, Gallicchio M, Biffo S, Bardelli A: Deregulation of the PI3K and KRAS signaling pathways in human cancer cells determines their response to everolimus. J Clin Invest 2010, 120:2858-2866.

\section{doi:10.1186/bcr3039}

Cite this article as: Miller TW, et al:: Mutations in the phosphatidylinosito 3-kinase pathway: role in tumor progression and therapeutic implications in breast cancer. Breast Cancer Research 2011, 13:224. 